\title{
Livestock Management Practices followed by Kandi Farmers of Hoshiarpur District of Punjab, India
}

\author{
Gagandeep Singh $^{1^{*}}$, R.K. Sharma ${ }^{1}$, H.K. Verma ${ }^{2}$ and Jaswinder Singh ${ }^{3}$ \\ ${ }^{1}$ Regional Research and Training Centre of Guru Angad Dev Veterinary and Animal Sciences \\ University, Talwara, Hoshiarpur, Punjab, India \\ ${ }^{2}$ Directorate of Extension Education, GADVASU, Ludhiana, Punjab, India \\ ${ }^{3}$ Department of Veterinary and Animal Husbandry Extension Education, GADVASU, \\ Ludhiana, Punjab, India \\ *Corresponding author
}

\section{A B S T R A C T}

Keywords

Livestock,

Knowledge, Kandi area, Management, Punjab

Article Info

Accepted:

10 October 2019

Available Online:

10 November 2019
A study was conducted to identify common management practices followed by farmers in Kandi area. A total of 100 famers from four different villages of Block Talwara were selected and information was collected through a pre-tested schedule. It was observed that anestrous (56\%) and repeat breeding $(31 \%)$ were the two most common problems of the dairy animals of the area. Snake bite and diarrhea (any cause) was identified as the most common reasons for calf mortality. Ectoparasites such as ticks were reported by most of the farmers $(58 \%)$ on their dairy animals. Majority of the farmers $(69 \%)$ used to feed colostrum to their calves after placental shedding and milked their animals with thumb pressing/knuckling. Majority of them (69\%) also got their animals vaccinated against prevalent infectious diseases. Most of the farmers $(72 \%)$ were not aware of deworming practices.

\section{Introduction}

Livestock is an essential part of rural economy and is an important source of livelihood in the rural areas. It also helps in meeting nutritional requirement of farmer families in rural areas (Sabapara et al., 2010). Punjab is known for bringing green revolution in the country.
However, Kandi area (sub mountainous zone) is very different from rest of Punjab as agriculture in this area is dependent upon rain. Because of less availability of fertile land, there is acute scarcity of forages for animals. Despite vital importance of livestock in the livelihood of farmers, the productive ability of these animals is quite low in the area. Several 
factors are responsible for low production. Therefore, understanding of the livestock management practices followed by farmers is necessary to identify the strengths and weaknesses of the rearing systems in order to formulate suitable intervention policies. Hence the present investigation was undertaken to study the knowledge level of farmers regarding various livestock management practices followed by the farmers in the Kandi area of Hoshiarpur district of Punjab.

\section{Materials and Methods}

Present study was conducted in four villages (viz.-Bhatoli, Sathwan, Nathowal and Bhadyaran) falling in Kandi area of Block Talwara, District Hoshiarpur. From each village, twenty five farmers having dairy animals were selected randomly and information regarding various management practices was collected by visiting them personally. A pre-tested schedule was used for the purpose. The schedule contained different sections pertaining to personal details of the farmer, various management practice followed by them including housing, feeding reproduction, vaccination, deworming, disease status or any other problem. The data was, then, transferred to a data sheet and was analyzed.

\section{Results and Discussion}

\section{Breeding management practices}

The breeding management practices followed by livestock farmers of Kandi area of Hoshiarpur district has been presented in Table 1. All the farmers of the Kandi area relied on symptoms for detecting heat in dairy animals. Similar results were reported by Patel et al., (2014). More than half of the farmers (56\%) considered vaginal mucus discharge, bellowing, and frequent urination as signs of heat. Similar findings were reported by
Sreedhar et al., (2017), Patel et al., (2014), Tanwar et al., (2012) and Brar and Nanda (2004).

Similarly, majority of farmers (63\%) were dependent on natural service for breeding purposes. Only 22 per cent of the farmers practiced artificial insemination for their animals. The results are in consonance with those reported by Tanwar et al., (2012), Sinha et al., (2010) and Sreedhar et al., (2017). Only one report (Prajapathi et al., 2015) stated that 88 per cent of rural farmers and 70 per cent of urban farmers used scientific method of artificial insemination in their dairy animals. The higher use of $\mathrm{AI}$ in the last report could be due to greater awareness of the farmers because of presence of Agricultural University in the district from where the respondents were interviewed.

Majority of farmers $(43 \%)$ allowed their animals bred within 12-18 hours of heat detection. Only 35 per cent famers delayed breeding beyond 18 hour of heat while rest of the farmers bred their animals immediately after detecting heat symptoms. Majority of the farmers, thus, have awareness of right time of insemination/natural service. Similar results were reported by Sreedahar et al., (2017) and Tanwar et al., (2012).

Majority of the farmers were reluctant to get their animals checked for pregnancy status by any Livestock Inspector or Veterinarian. The farmers were of the view that the procedure for pregnancy diagnosis was not safe for their animals. Most of the animals tended to abort following pregnancy checks. This could be because of the fact that most of such pregnancy checks might be performed by layman inseminators.

For better profitability, it is necessary that animal should return to heat within a period of 3 months following parturition. In the present 
study, it was observed that most of the animals took more than 5 months to exhibit heat signs. The longer postpartum anoestrous period could be due to low nutritional status of the animal as there is severe shortage of green fodder available in the area and only 19 per cent farmers supplemented mineral mixture to their animals while only 20 per cent farmers used to feed uromin licks to the their animals during study period. Similar findings were reported by Sreedhar et al., (2017), however, Gupta et al., (2008) in their study reported that higher proportion of dairy animals were rebred within 2-3 months after parturition which is contrary to our findings.

Majority of the farmers used to dry their pregnant cows 2-5 months before expected date of calving. Anestrous (56\%) and repeat breeding $(31 \%)$ were the two most common problems faced by the farmers of Kandi area. The high incidence of these two problems could be due to imbalance in the feeding of dairy animals leading to various deficiencies.

Table.1 Breeding management practices followed by farmers in Kandi area

\begin{tabular}{|c|c|c|c|}
\hline S.No. & Parameter & $\begin{array}{c}\text { Total } \\
(\mathrm{N}=100)\end{array}$ & Percent \\
\hline 1. & $\begin{array}{c}\text { Method of Heat Detection: } \\
\text { Symptoms } \\
\text { Teaser Bull }\end{array}$ & 100 & 100 \\
\hline 2. & $\begin{array}{c}\text { Symptoms of heat detection: } \\
\text { Mucus discharge } \\
\text { Mucus + Bellowing } \\
\text { Mucus + Bellowing + Frequent urination }\end{array}$ & $\begin{array}{l}18 \\
26 \\
56\end{array}$ & $\begin{array}{l}18 \\
26 \\
56\end{array}$ \\
\hline 3. & $\begin{array}{c}\text { Breeding of females: } \\
\text { A.I. } \\
\text { Natural service } \\
\text { Combination of both }\end{array}$ & $\begin{array}{l}22 \\
63 \\
15\end{array}$ & $\begin{array}{l}22 \\
63 \\
15\end{array}$ \\
\hline 4. & $\begin{array}{c}\text { Insemination time: } \\
\text { Immediately after heat } \\
\text { Within } 12-18 \mathrm{hr} \\
\text { After } 18 \mathrm{hr}\end{array}$ & $\begin{array}{l}22 \\
43 \\
35\end{array}$ & $\begin{array}{l}22 \\
43 \\
35\end{array}$ \\
\hline 5. & $\begin{array}{l}\text { Breeding after calving: } \\
2-5 \text { months } \\
>5 \text { months } \\
\text { After 1year }\end{array}$ & $\begin{array}{l}18 \\
63 \\
19\end{array}$ & $\begin{array}{l}18 \\
63 \\
19\end{array}$ \\
\hline 6. & $\begin{array}{c}\text { Pregnancy diagnosis: } \\
\text { Practiced } \\
\text { Not practiced }\end{array}$ & $\begin{array}{l}18 \\
82\end{array}$ & $\begin{array}{l}18 \\
82\end{array}$ \\
\hline 7. & Anestrous & 56 & 56 \\
\hline 8. & RepeatBreeding & 31 & 31 \\
\hline 9. & Retention of Placenta & 14 & 14 \\
\hline
\end{tabular}


Table. 2 Health care management practices followed by farmers in Kandi area

\begin{tabular}{|c|c|c|c|}
\hline S No & Parameter & $\begin{array}{c}\text { Total } \\
(\mathbf{N}=100)\end{array}$ & Percent \\
\hline 1. & $\begin{array}{l}\text { Vaccination status } \\
\text { Yes } \\
\text { No }\end{array}$ & $\begin{array}{l}81 \\
19\end{array}$ & $\begin{array}{l}81 \\
19\end{array}$ \\
\hline 2. & $\begin{array}{c}\text { Frequency of Vaccination } \\
\text { Every year } \\
\text { Alternate year } \\
\text { Once in 2-3 years }\end{array}$ & $\begin{array}{l}84 \\
16\end{array}$ & $\begin{array}{l}84 \\
16\end{array}$ \\
\hline 3. & $\begin{array}{c}\text { Ectoparasite present in the herd } \\
\text { Ticks } \\
\text { Ticks and Lice } \\
\text { Mosquitoes } \\
\text { Flies } \\
\text { No ectoparasites }\end{array}$ & $\begin{array}{l}58 \\
22 \\
20\end{array}$ & $\begin{array}{l}58 \\
22 \\
20\end{array}$ \\
\hline 4. & $\begin{array}{c}\text { Control for ectoparasites } \\
\text { Followed } \\
\text { Not followed }\end{array}$ & $\begin{array}{l}88 \\
12 \\
\end{array}$ & $\begin{array}{l}88 \\
12 \\
\end{array}$ \\
\hline 5. & $\begin{array}{c}\text { Method of application of acaricide } \\
\text { Scrubbing } \\
\text { Spraying } \\
\text { Pour on } \\
\text { Scrubbing and pour on }\end{array}$ & $\begin{array}{c}40 \\
0 \\
22 \\
26\end{array}$ & $\begin{array}{c}40 \\
0 \\
22 \\
26\end{array}$ \\
\hline 6. & $\begin{array}{c}\text { De-worming in dairy animals: } \\
\text { Practiced } \\
\text { Not practiced }\end{array}$ & $\begin{array}{l}28 \\
72\end{array}$ & $\begin{array}{l}28 \\
72\end{array}$ \\
\hline 7. & $\begin{array}{c}\text { De-worming in calf: } \\
\text { Practiced } \\
\text { Not practiced }\end{array}$ & $\begin{array}{l}20 \\
80\end{array}$ & $\begin{array}{l}20 \\
80\end{array}$ \\
\hline 8. & $\begin{array}{c}\text { Naval cord disinfection: } \\
\text { Yes } \\
\text { No }\end{array}$ & $\begin{array}{l}18 \\
82 \\
\end{array}$ & $\begin{array}{l}18 \\
82 \\
\end{array}$ \\
\hline 9. & $\begin{array}{c}\text { Treatment of sick animal by: } \\
\text { Local knowledge } \\
\text { Livestock inspector } \\
\text { Veterinary officers } \\
\text { Veterinary officer and Livestock Inspector }\end{array}$ & $\begin{array}{l}08 \\
14 \\
22 \\
56\end{array}$ & $\begin{array}{l}08 \\
14 \\
22 \\
56\end{array}$ \\
\hline 10. & $\begin{array}{c}\text { Use of mineral mixture } \\
\text { Yes } \\
\text { No }\end{array}$ & $\begin{array}{l}19 \\
81 \\
\end{array}$ & $\begin{array}{l}19 \\
81 \\
\end{array}$ \\
\hline 13. & $\begin{array}{c}\text { Use of Uromin Lick } \\
\text { Yes } \\
\text { No }\end{array}$ & $\begin{array}{l}20 \\
80\end{array}$ & $\begin{array}{l}20 \\
80 \\
\end{array}$ \\
\hline 14. & $\begin{array}{c}\text { Making of Silage/Hay } \\
\text { Yes } \\
\text { No }\end{array}$ & $\begin{array}{c}0 \\
100\end{array}$ & $\begin{array}{c}0 \\
100\end{array}$ \\
\hline 15. & $\begin{array}{l}\text { Colostrum feeding to calves } \\
\text { Within } 2 \text { hours of birth } \\
2-8 \text { hours of birth } \\
\text { After shedding of placenta }\end{array}$ & $\begin{array}{l}13 \\
18 \\
69\end{array}$ & $\begin{array}{l}13 \\
18 \\
69\end{array}$ \\
\hline 16. & $\begin{array}{c}\text { Type of milk feeding } \\
\text { Suckling } \\
\text { Hand feeding }\end{array}$ & $\begin{array}{c}94 \\
6 \\
\end{array}$ & $\begin{array}{c}94 \\
6 \\
\end{array}$ \\
\hline 17. & $\begin{array}{l}\text { Weaning age } \\
1-2 \text { months } \\
2-3 \text { months } \\
>3 \text { months }\end{array}$ & $\begin{array}{l}11 \\
29 \\
52\end{array}$ & $\begin{array}{l}11 \\
29 \\
52\end{array}$ \\
\hline
\end{tabular}


Table.3 Milking management practices followed by farmers in Kandi area

\begin{tabular}{|c|c|c|c|}
\hline S No & Parameter & $\begin{array}{c}\text { Total } \\
(\mathrm{N}=100)\end{array}$ & Percent \\
\hline \multirow[t]{3}{*}{1.} & Washing of teat before milking & & \\
\hline & Yes & 77 & 77 \\
\hline & No & 23 & 23 \\
\hline \multirow[t]{3}{*}{2.} & Washing hand before milking: & & \\
\hline & Yes & 90 & 90 \\
\hline & No & 10 & 10 \\
\hline \multirow[t]{4}{*}{3.} & Milking methods: & & \\
\hline & Full hand & 24 & 24 \\
\hline & Knuckling & 69 & 69 \\
\hline & Stripping & 07 & 07 \\
\hline \multirow[t]{3}{*}{4.} & Post milking teat dip & & \\
\hline & Yes & 13 & 13 \\
\hline & No & 87 & 87 \\
\hline \multirow[t]{3}{*}{5.} & Testing of mastitis control: & & \\
\hline & Yes & 0 & 0 \\
\hline & No & 100 & 100 \\
\hline \multirow[t]{4}{*}{6.} & Disposal of milk: & & \\
\hline & Co-operative Society & 0 & 0 \\
\hline & Vendors/ Middle man & 4 & 4 \\
\hline & Home use & 96 & 96 \\
\hline \multirow[t]{6}{*}{7.} & Milk yield & & \\
\hline & No milk yield & 05 & 05 \\
\hline & $<2$ litre & 19 & 19 \\
\hline & 2-5 litre & 54 & 54 \\
\hline & 5-8 litre & 14 & 14 \\
\hline & $>10$ litre & 08 & 08 \\
\hline
\end{tabular}


Table.4 Housing management practices followed by farmers in Kandi area

\begin{tabular}{|c|c|c|c|}
\hline S.No. & Parameter & $\begin{array}{c}\text { Total } \\
(\mathrm{N}=100)\end{array}$ & Percent \\
\hline 1. & $\begin{array}{l}\text { Direction of Shed } \\
\text { East west } \\
\text { Others } \\
\text { No shed }\end{array}$ & $\begin{array}{l}26 \\
63 \\
11\end{array}$ & $\begin{array}{l}26 \\
63 \\
11\end{array}$ \\
\hline 2. & $\begin{array}{l}\text { Height of roof } \\
>10 \text { feet } \\
<10 \text { feet } \\
\text { No shed }\end{array}$ & $\begin{array}{l}52 \\
33 \\
11\end{array}$ & $\begin{array}{l}52 \\
33 \\
11\end{array}$ \\
\hline 3. & $\begin{array}{l}\text { Type of roof } \\
\text { Thatched } \\
\text { Asbestos/Tin } \\
\text { No shed }\end{array}$ & $\begin{array}{l}18 \\
59 \\
11\end{array}$ & $\begin{array}{l}18 \\
59 \\
11\end{array}$ \\
\hline 4. & $\begin{array}{c}\text { Floor area per animal } \\
\text { Sufficient } \\
\text { Insufficient }\end{array}$ & $\begin{array}{l}70 \\
58\end{array}$ & $\begin{array}{l}70 \\
58\end{array}$ \\
\hline 5. & $\begin{array}{l}\text { Type of floor } \\
\text { Pucca } \\
\text { Bricks } \\
\text { Kutcha }\end{array}$ & $\begin{array}{l}25 \\
07 \\
54\end{array}$ & $\begin{array}{l}25 \\
07 \\
54\end{array}$ \\
\hline 6. & $\begin{array}{l}\text { Level of floor } \\
\text { Sloppy } \\
\text { Levelled } \\
\text { Uneven }\end{array}$ & $\begin{array}{l}10 \\
23 \\
67\end{array}$ & $\begin{array}{l}10 \\
23 \\
67\end{array}$ \\
\hline 7. & $\begin{array}{l}\text { Cleanliness of floor } \\
\text { Clean and dry } \\
\text { Wet floor }\end{array}$ & $\begin{array}{l}38 \\
62\end{array}$ & $\begin{array}{l}38 \\
62\end{array}$ \\
\hline 8. & $\begin{array}{l}\text { Ventilation } \\
\text { Good } \\
\text { Fair } \\
\text { Poor }\end{array}$ & $\begin{array}{l}62 \\
31 \\
07\end{array}$ & $\begin{array}{l}62 \\
31 \\
07\end{array}$ \\
\hline 9. & $\begin{array}{l}\text { Tree Shade } \\
\text { Available } \\
\text { Not available }\end{array}$ & $\begin{array}{l}78 \\
22\end{array}$ & $\begin{array}{l}78 \\
22\end{array}$ \\
\hline 10. & $\begin{array}{c}\text { Cooling in Summer } \\
\text { Yes } \\
\text { No }\end{array}$ & $\begin{array}{l}90 \\
10\end{array}$ & $\begin{array}{l}90 \\
10\end{array}$ \\
\hline 11. & $\begin{array}{c}\text { Provision of water for drinking Purpose } \\
\text { Sufficient } \\
\text { Insufficient }\end{array}$ & $\begin{array}{l}67 \\
33\end{array}$ & $\begin{array}{l}67 \\
33\end{array}$ \\
\hline 12. & $\begin{array}{c}\text { Provision of Bedding } \\
\text { Yes } \\
\text { No }\end{array}$ & $\begin{array}{l}22 \\
78\end{array}$ & $\begin{array}{l}22 \\
78\end{array}$ \\
\hline 13. & $\begin{array}{c}\text { Exercise } \\
\text { Free all the time } \\
\text { Tied all the time } \\
\text { Tied but moved during day night shift }\end{array}$ & $\begin{array}{c}0 \\
84 \\
16\end{array}$ & $\begin{array}{c}0 \\
84 \\
16\end{array}$ \\
\hline 14. & $\begin{array}{c}\text { Grazing done } \\
\text { Yes } \\
\text { No }\end{array}$ & $\begin{array}{l}16 \\
84\end{array}$ & $\begin{array}{l}16 \\
84\end{array}$ \\
\hline
\end{tabular}


Ahmet et al., (2008) reported that the major possible cause of reproductive failure in dairy animals is the absence of mineral mixture in the concentration ration. It is very well known that proper feeding of animals is important for maintaining proper reproductive status of dairy animals (Venkatisubramanian, 1994, Singh and Brar, 2008). Poor quality of semen, untrained inseminators and farmer's inability to present the animal at proper time of heat for artificial insemination could also lead to repeat breeding in dairy cows (Meena and Malik, 2009, Venkatisubramanian, 1994, Venkatisubramanian and Rao, 1993).

\section{Health care management practices}

The results of health care management practices followed by farmers in Kandi area has been presented in Table 2. Around 80 per cent of the farmers got their animals vaccinated regularly for Foot and Mouth Disease (FMD) and Haemorrhagic Septicaemia (HS) at the Government Veterinary Hospitals. Similarly, high level of vaccination in animals in rural areas was also reported in other studies (Patel et al., 2014, Sinha et al., 2010 and Prasad et al., 2002).

Deworming of dairy animals is an important practice as it protects them from endoparasites, however, in the present study, only very few farmers tended to deworm their animals and calves. This could be due to lack of awareness regarding the harmful effect of parasitic load on animal body. Similar findings of lower deforming practices in dairy animals and calves was also reported by Patel et al., (2014) and, Singh and Singh (2000).

Naval cord disinfection in young calves is very important to protect them from various diseases. This practice was also followed by very few farmers (18\%). It could also be due to lack of awareness. Similar results were reported by Patel et al., (2014).
Majority of farmers reported presence of ectoparasites (ticks and lice) on their animals and eighty eight per cent of the farmers had adopted various methods (such as use of acaricides as scrub or pour on) to control the ectoparasites. However, Patel et al., (2014) reported that only 11 per cent of the tribal farmers of Narmada Valley used to apply various acaricides for ectoparasite control in their animals. This could be due to lack of awareness in tribal farmers.

Inadequate feeding of colostrum to calves remains one of the most serious hazards for calf welfare (European Food Safety Authority, 2006). Maximum absorption of immunoglobulins occurs during first four hours of birth and it decreases rapidly after 12 hours (Weaver et al., 2000).

In the present study, it was observed that 69 per cent of the farmers were feeding colostrum to the calves after the shedding of placenta. It is a very common myth among the farmers of the area that if colostrum is given to calves before the shedding of placenta, toxins will be transferred to calf's body. Therefore, the farmers wait for the shedding of placenta and feed the calves after the shedding. Due to this reason, incidence of diarrhea in calves is very high and a large number of farmers cited diarrhea as the reason of death in calves.

Another important reason for calf mortality identified in this study was the snake bite. Most of the animals including calves were tethered inside the sheds that have no boundary wall. The snake, thus, have easy access to dairy animals and their calves.

\section{Milking management practices followed by farmers in Kandi area}

Perusal of Table 3 reveals that 69 per cent of farmers were following knuckling (wrong method) whereas only 24 percent of the 
farmers were practicing full hand milking method for the milking of animals. Similar finding of high rate of knuckling practice was reported by Patel et al., 2014, Sinha et al., (2010). Low percentage of full hand milking reported in our study could be due to lack of awareness regarding the correct method of milking. However, Bashir and Kumar (2013) reported that 76 per cent of the farmers in Kerala were using full hand method of milking. High rate of following full palm method of milking in Kerala could be due to high rate of literacy.

Majority of farmers washed their hands (90\%) and teats $(77 \%)$ before milking, however, only 13 per cent were practicing post milking teat dip. Similar results of post milking teat dipping were also reported by Patel et al., (2014).

Low level of milk production (2-5 litres/ day) was reported by 54 per cent of the farmers and it could be due to non-descript nature of their breed and scarcity of green fodder in the area. Only 14 per cent of the farmers reported a milk yield of 5-8 litres/day. Most of the famers were using milk for their home use only.

\section{Housing management practices followed by farmers in Kandi area}

Majority of farmers (63\%) had no idea about the direction of an ideal shed. Only 26 per cent of farmers had constructed animal sheds in east-west direction while 11 per cent farmers did not have any shed at all. For proper ventilation it is necessary that height of the shed should be no less than 10 feet and in our study 52 per cent of the farmers have their sheds for animal house greater than 10 feet, which will help in keeping good ventilation in their sheds (Table 4). Regarding the material of the shed 71 per cent of the respondents were having their sheds made of Asbestos/Tin, while 18 per cent of the farmers were having their shed made of thatched roof. Sixty eight per cent of the farmers were having kutcha type of floor in their sheds and 25 per cent of the farmers were having pucca floors and the level of floor was uneven in 67 per cent of farmers shed and the floor was wet in majority of the farms depicting the lack of awareness of the farmers regarding the cleanliness of farms which will help in keeping the animals healthy. Ventilation was good $(62 \%)$ in most of the farms as large number of trees are present $(78 \%)$ along the sheds of the animals which helps in keeping the shed of the animal cool and also preventing it from direct sun light. Eighty four per cent of the farmers keep their animals tied all the time and eighteen per cent of the farmers send their animals for grazing outside. Similar findings regarding the housing management practices were reported by Meena et al., (2007) and Singh et al., (2015). From the present study it was concluded that farmers are not fully aware about various livestock management practices and further trainings are required for the farmers to increase their knowledge and awareness regarding the scientific ways of livestock rearing.

\section{References}

Ahmet, C., Ilker, S., Hasan, A. and Seyrek, K. 2008. Concentrations of some elements in dairy cows with reproductive disorders. Bulletin Vet. Institute, Pulawy. 52: 109-112.

Bashir, B.P. and Kumar, V.G. 2013. Milking management practices followed in selected areas of the Kottayam district of Kerala state. J. Life Sci. 5(1): 53-55.

Brar, P.S. and Nanda, A.S. 2004. Impact of conventional managemental practices on reproductive performance of rural buffaloes. Indian J. Anim. Reproduction. 25(2): 94-98.

European Food Safety Authority. 2006. The risks of poor welfare in intensive calf farming systems. An update of the 
Scientific Veterinary Committee Report on the Welfare of Calves. European Food Safety Authority, Parma, Italy.

Gupta, D.C., Suresh, A and Mann, J.S. 2008. Management practices and productivity status of cattle and buffaloes in Rajasthan. Ind. J. Anim. Sci. 78 (7): 769-774.

Meena, H.R., Ram, H., Singh, S.K., Mahapatra, R.K., Sahoo, A. and Rasool, T.J. 2007. Animal husbandry practices at high altitude (>6000 feet) in Kumaon region of Uttrakhand, India. Livestock Res. Rural Dev. 19(11): 163-167.

Meena, M.S. and Malik, B.S. 2009. Participatory identification of reproductive problems among dairy animals and constraints faced by farmers in Haryana. Indian J. Anim. Sci. 79(11): 1172-1175.

Patel, N.B., Kavad1, S.D. and Rao, T.K.S. 2014. Eco-friendly livestock management practices followed by tribal households of Narmada valley region of India. J. Applied Natural Sci. 6 (2): 512-518.

Prasad, G., Venkatesh, Nataraju, M. S., Nagaraju, S. and Gopinathan, N. 2002. Knowledge of dairy management practices among the farmers of central dry zone in Karnatka state. The Vet. 26:13-18.

Sabapara, G. P., Desai, P. M., Singh, R. R. and Kharadi, V. B. 2010.Breeding and health care management status of dairy animals in the tribal area of South Gujarat. Indian J. Animal Sci. 74 (9): 997-1002.

Singh A.K and Brar P.S. 2008. Suckling and reproduction in buffalo: A review. Indian J. Anim. Sci. 78(12):1342-52.

Singh M., Chakravarty R., Bhanotra A. and Kumar M. 2015. Study on Dairy Animal Health and Housing Management
Practices followed Tribal Area of Ranchi, Jharkhand. International J. Farm Sci. 5(3): 199-206.

Singh, R. and Singh, N. 2000. Influence of socio-economic variables on adoption of buffalo calf rearing management practices in rural Haryana. Indian $\mathrm{J}$. Animal Sci. 70 (3): 325-330.

Sinha, R.R.K., Dutt, T., Singh, R.R., Singh, M. and Bhusan, B. 2010. Studies on breeding and health care management practices in rural, semi-urban and urban areas of Bareily district of Uttar Pradesh. Indian J. Anim. Prod. Mgmt. 26(1-2): 11-15.

Sreedhar, S. Nagarjuna Reddy, A., Sudhakar, B.V. and Ramesh Babu, P. 2017. Breeding management practices and reproductive disorders in indigenous Cattle and Buffaloes. Global J. Biosci. Biotech. 6 (3): 504-508.

Tanwar, P.S., Kumar, Y. and Sankhala, G. 2012. Study on breeding and feeding management practices followed by members and non-members of dairy cooperatives in Jaipur district of Rajasthan. Indian J. Dairy Sci. 65(6): 508-513.

Venkatisubramanian $\quad$ V. 1994. 'Multidimensional analysis of crossbreeding programme in Tamil Nadu.' Ph.D. Thesis, NDRI, Karnal.

Venkatisubramanian V. and Rao S.V.V. 1993. Incidence of health disorders in crossbreds and indigenous cattle under field condition. Indian Dairy Sci. 46(7): 302-306.

Weaver, D. M., Tyler, J.W., VanMetre, D.C., Hostetler, D.E. and Barrington. G.M. 2000. Passive transfer of colostral immunoglobulins in calves. J. Vet. Intern. Med. 14: 569-577.

\section{How to cite this article:}

Gagandeep Singh, R.K. Sharma, H.K. Verma and Jaswinder Singh. 2019. Livestock Management Practices followed by Kandi Farmers of Hoshiarpur District of Punjab. Int.J.Curr.Microbiol.App.Sci. 8(11): 982-990. doi: https://doi.org/10.20546/ijcmas.2019.811.115 